\title{
Drastic effect of ranibizumab on choroidal neovascularization in idiopathic angioid streaks
}

\author{
Efeito dramático do ranibizumabe na neovascularização de coroide em estrias angióides idiopáticas
}

Umit Yolcu ${ }^{1}$, Fatih C. Gundogan², Oktay Diner ${ }^{2}$

\begin{abstract}
A 28-year-old man presented with bilateral vision loss. His best-corrected visual acuity (BCVA) was 0.3 in the right eye (OD) and 0.6 in the left eye (OS). Fundoscopy and fluorescein angiography showed angioid streaks encircling the optic discs of both eyes (OU). Spectral Domain Optical Coherence Tomography (SD-OCT) showed bilateral macular serous detachment. Systemic and ocular screening tests showed no specific cause for the angioid streaks. The patient had previously received pegaptanib sodium injection on three occasions, photodynamic therapy in OS, and no treatment in OD. Upon intravitreal injection of ranibizumab (twice in OU), subretinal fluid was nearly eliminated in OU. BCVA increased to 0.6 in OD and 0.9 in OS, and remained improved until 6 months after treatment.
\end{abstract}

Keywords: Angioid streaks; Antibodies, monoclonal/therapeutic use; Antibodies, monoclonal/drug effects; Antibodies, monoclonal, humanized/drug effects; Choroidal neovascularization/drug therapy; Case reports

\section{RESUMO}

Um homem de 28 anos apresentou-se com perda de visão bilateral. A melhor acuidade visual corrigida (BCVA) era 0,3 no ol ho direito (OD) e 0,6 no ol ho esquerdo (OS). A fundoscopia e a angiofluoresceinografia demonstraram estrias angióides ao redor dos discos ópticos em ambos os olhos (OU). A tomografia de coerência óptica de domínio espectral (SD-OCT) demonstrou descolamento seroso macular bilateral. Testes de triagem sistêmicas e oculares não mostraram causa especifica para estrias angióides. O paciente tinha um historia de três tratamentos com injeção de pegaptanibe sódico e terapia fotodinâmica em OS e nenhum tratamento em OD. Após a injeção intravítrea de ranibizumabe (duas vezes em OU), fluido sub-retiniano quase desapareceu em OU. BCVA melhorou para 0,6 em OD e 0,9 em OS e não se alterou até o sexto mês de tratamento.

Descritores: Estrias angióides; Anticorpos monoclonais/uso terapêutico; Anticorpos monoclonais/efeitos dedrogas; Anticorposmonoclonais humanizados/efeito dedrogas; Neovascularização de coroide/efeito de drogas; Relatos de casos

\section{INTRODUCTION}

Angioid streaks are irregularly radiating grey lines that extend from the peripapillary region to the peripheral retina, which result from rupture or dehiscence of a fragile, and typically calcified, Bruch's membrane. Angioid streaks may be observed in isolation, but are often associated with systemic diseases such as Paget's disease, pseudoxanthoma elasticum, Ehlers-Danlos syndrome, or sickle cell anemia. The main cause of severe visual loss in cases of angioid streaks is the development of choroidal neovascularization (CNV) ${ }^{(1)}$. CNV develops in $42 \%$ to $86 \%$ of eyes with angioid streaks and typically has a poor outcome(2). Different therapeutic strategies have been used to control CNV secondary to angioid streaks, including laser photocoagulation, photodynamic therapy (PDT), surgical removal, transpupillary thermotherapy, and intravitreal injection of pegaptanib, bevacizumab, or ranibizumab ${ }^{(3)}$. The latest reports on the treatment of CNV secondary to angioid streaks have focused mainly on the use of ranibizumab, which is a recombinant humanized monoclonal antibody that acts as a vascular endothelial growth factor inhibitor (anti-VEGF).

In this report, we present a case of persistent CNV with serous macular detachment secondary to idiopathic angioid streaks. The patient was treated with intravitreal ranibizumab injections. Following these injections, the patient had a drastic increase in best corrected visual acuity (BCVA).

\section{CASE REPORT}

A 28-year-old man presented with bilateral vision blurring. He had no history of any systemic disease or ocular trauma, but had received photodynamic therapy (PDT) seven years prior following a diagnosis of subfoveal CNV and pigment epithelial detachment in the left eye (OS). Following PDT, his BCVA in OS increased from 0.16 to 0.9.

At the time of this visit, the patient's BCVA was 0.3 in the right eye (OD) and 0.6 in OS. Examination of the anterior segments of both eyes (OU) did not uncover any problems. Examination of the posterior segments uncovered bilateral subretinal grayish branching streaks that extended from the peripapillary regions to the periphery, and multiple "peau d'orange" pigmentation areas. Fluorescein angiography (FA) revealed bilateral hyperfluorescent lines corresponding to the angioid streaks and bilateral CNV membranes (Figure 1 A), and late staining in the macula in OS (Figure 1 D). Spectral Domain Optical Coherence Tomography (SD-OCT) revealed subfoveal fluid accumulation with a central retinal thickness of 234 microns in OD (Figure $1 \mathrm{~B}, 1 \mathrm{C}$ ). Subretinal scar formation was detected with a central macular thickness of 198 microns in OS (Figure $1 \mathrm{E}$ ). There was also minimal extra-foveal subretinal fluid accumulation present in the upper temporal region of the macula in OS (Figure $1 \mathrm{~F}$ ).

Hematology, cardiology, dermatology, and endocrinology consultations were negative for sickle cell anemia, Ehler-Danlos syndro-
Funding: No specific financial support was available for this study

Disclosure of potential conflicts of interest: None of the authors have any potential conflict of interest to disclose.

Corresponding author: Umit Yolcu. Siirt Military Hospital - Department of Ophthalmology - Siirt-56100 Turkey - E-mail: umit_yolcu@hotmail.com 
me, pseudoxantoma elasticum, and Paget's disease. After informed consent was obtained from the patient, an injection of intravitreal ranibizumab $(0.5 \mathrm{mg})$ was administered in OU. One month after injection, BCVA was 0.6 in OD and 0.9 in OS. SD-OCT revealed decreased subretinal fluid in OD and disappearance of the fluid in OS a month after injection. In addition, central macular thickness had decreased to $183 \mathrm{~nm}$ in OD and $194 \mathrm{~nm}$ in OS. Due to this positive response, a second injection of ranibizumab was administered in OD. Two months after the second injection, BCVA was 0.6 in OD and 0.9 in OS, and central macular thickness was $188 \mathrm{~nm}$ in OD and $196 \mathrm{~nm}$ in OS. At 6-month follow-up, macular SD-OCT revealed minimal submacular fluid in OU (Figure 2 B, 2 D).


Figure 1. Fluorescein Angiography (FA) and SD-OCT images pre-ranibizumab treatment. (A) FA of the right eye (OD), demonstrating hyperfluorescence in the foveal region. (B, C) SD-OCT of OD, revealing serous macular detachment. (D) FA of the left eye (OS), demonstrating staining between the optic disc and fovea, corresponding to a subretinal scar. (E) SD-OCT of OS, revealing irregularity in the macular photoreceptor inner segment-outer segment junction, corresponding to a subretinal scar. (F) SD-OCT of OD, revealing extra-foveal serous detachment.

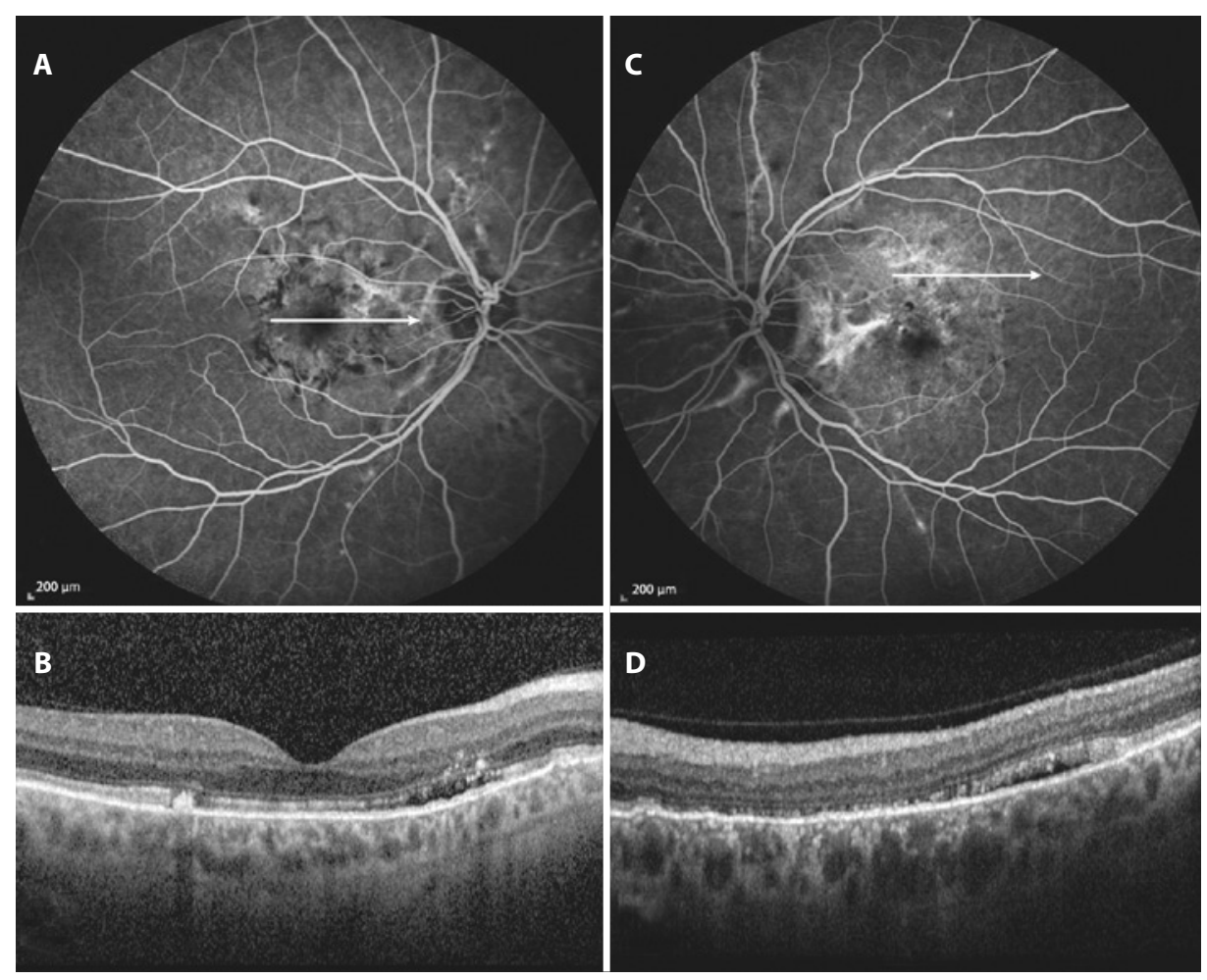

Figure 2. Fluorescein Angiography (FA) and SD-OCT images. (A) FA of OD, demonstrating hyperfluorescence in the foveal region (B) SD-OCT of OD, revealing minimal submacular fluid. (C) FA of OS, demonstrating staining between the optic disC and fovea, corresponding to a subretinal scar. (D) SD-OCT of OS, revealing minimal submacular fluid. 


\section{DISCUSSION}

Angioid streaks may cause severe visual loss due to the development of CNV. A previous study has shown that $5 \%$ of all CNV lesions are related to angioid streaks ${ }^{(4)}$. CNV is reported to occur in up to $86 \%$ of patients with angioid streaks, resulting in serious visual disability ${ }^{(5)}$. Laser photocoagulation, photodynamic therapy, surgical excision, and intravitreal injections of anti-VEGF agents have been used to treat CNV lesions associated with angioid streaks.

In cases where laser photocoagulation has been used to treat extrafoveal CNV secondary to angioid streaks, recurrences have generally been reported following short-term cessation of disease activity (less than one year) ${ }^{(2,6)}$. In a large study, Pece et al. evaluated treatment with direct laser photocoagulation in 66 eyes of 52 consecutive patients who had CNV due to angioid streaks $s^{(7)}$. After a mean follow-up period of 34.5 months, the authors reported a significant BCVA increase in the first year of the treatment and no significant change thereafter. In that study, CNV was eliminated in 31 eyes (47\%). Furthermore, Karacorlu et al. ${ }^{\left({ }^{(8)}\right.}$ reported beneficial effects of PDT on CNV, though several other studies have reported no positive effect of PDT in CNV patients. It has been generally agreed that following PDT treatment the greatest linear CNV diameter, which indicates lesion size, is increased at the time of final examination when compared to initial lesion diameter ${ }^{(5)}$, indicating disease progression despite PDT.

Anti-VEGF treatment of CNV due to angioid streaks was first reported by Teixeira et al. ${ }^{(9)}$ who reported increased BCVA and decreased disease activity following bevacizumab injection. In addition, in 2007 Lommatzsch et al. reported a single case of CNV due to angioid streaks ${ }^{(10)}$. The authors reported that there was deterioration in BCVA and leakage of CNV after treatment with PDT alone, but found an increase in BCVA and transition of CNV into a fibrotic scar following the injection of bevacizumab. After these reports, several case reports and studies also reported a beneficial effect of anti-VEGF agents on CNV due to angioid streaks. For example, Shah and Amoaku reported increased or stabilized BCVA in 11 of 12 eyes following intravitreal ranibizumab injections ${ }^{(11)}$. Similarly, Finger et al. reported a beneficial effect of ranibizumab on central visual function in seven patients with CNV related to pseudoxanthoma elasticum ${ }^{(12)}$. Across these studies and others, the frequency of injections and the treatment regimen have differed largely.
Similar to other studies, the CNV case described here regressed following two injections of ranibizumab administered 1 month apart. BCVA in OU increased drastically after the first injection. A second injection was performed and BCVA increase obtained after the first injection persisted for 6 months in OU. It is possible that the positive results of intravitreal anti-VEGF injections may be related to the disruption of Bruch's membrane and the damage to the retinal pigment epithelium, as this may enhance the delivery of the antibody to the CNV lesion. For this reason, anti-VEGF agents may be more effective in CNV secondary to angioid streaks than in CNV secondary to age-related macular degeneration.

\section{REFERENCES}

1. Georgalas I, Papaconstantinou D, Koutsandrea C, Kalantzis G, Karagiannis D, Georgopoulos G, et al. Angioid streaks, clinical course, complications, and current therapeutic management. Ther Clin Risk Manag. 2009;5(1):81-9.

2. Clarkson JG, Altman RD. Angioid streaks. Surv Ophthalmol. 1982;26(5):235-46.

3. Gupta B, Elagouz M, Sivaprasad S. Intravitreal bevacizumab for choroidal neovascularisation secondary to causes other than age-related macular degeneration. Eye (Lond). 2010;24(2):203-13.

4. Cohen SY, Laroche A, Leguen Y, Soubrane G, Coscas GJ. Etiology of choroidal neovascularization in young patients. Ophthalmology. 1996;103(8):1241-4.

5. Gliem M, Finger RP, Fimmers R, Brinkmann CK, Holz FG, Charbel Issa P. Treatment of choroidal neovascularization due to angioid streaks: a comprehensive review. Retina. 2013:33(7):1300-14.

6. Meislik J, Neldner K, Reeve EB, Ellis PP. Laser treatment in maculopathy of pseudoxanthoma elasticum. Can J Ophthalmol. 1978;13(3):210-2.

7. Pece A, Avanza P, Galli L, Brancato R. Laser photocoagulation of choroidal neovascularization in angioid streaks. Retina. 1997;17(1):12-6.

8. Karacorlu M, Karacorlu S, Ozdemir H, Mat C. Photodynamic therapy with verteporfin for choroidal neovascularization in patients with angioid streaks. Am J Ophthalmol. 2002;134(3):360-6.

9. Teixeira A, Moraes N, Farah ME,Bonomo PP. Choroidal neovascularization treated with intravitreal injection of bevacizumab (Avastin) in angioid streaks. Acta Ophthalmol Scand. 2006;84(6):835-6.

10. Lommatzsch A, Spital G, Trieschmann M, Pauleikhoff D. [Intraocular application of bevacizumab for the treatment of choroidal neovascularization secondary to angioid streaks]. Ophthalmologe. 2007;104(4):325-8. German.

11. Shah M, Amoaku WM. Intravitreal ranibizumab for the treatment of choroidal neovascularisation secondary to angioid streaks. Eye (Lond). 2012;26(9):1194-8.

12. Finger RP, Charbel Issa P, Hendig D, Scholl HP, Holz FG. Monthly ranibizumab for choroidal neovascularizations secondary to angioid streaks in pseudoxanthoma elasticum: a one-year prospective study. Am J Ophthalmol. 2011;152(4):695-703. 